\title{
Architektura odnawialna - nowe zagrożenia dla przyszłości architektury
}

\section{Renewable Architecture - New Threats to the Future of Architecture}

\begin{abstract}
Streszczenie
Naukowcy roztoczyli wizję wyczerpania złóż węgla i ropy naftowej, co spowodowało lawinowy rozwój badań nad nową generacją materiałów budowlanych oraz energią alternatywną. Niestety, każde rozwiązanie techniczne wykorzystujące materiały z odzysku ma tyleż samo zwolenników co i zagorzałych przeciwników.

Na szczęście już dawno stwierdzono, że przetwórstwo „śmieci” jest jedynym ratunkiem dla dynamicznie rozwijającej się cywilizacji. Traktując ogólną, technologiczną transformację ludzkości w skali globalnej jako specyficzny rodzaj produkcji, tworzący odpady i zanieczyszczenia, należy rozważyć wykorzystanie materiałów odnawialnych na skalę przemysłową. Architektura tworzy i zarazem ogranicza przestrzeń człowieka, do działań twórczych niezbędna jest energia, czyli bez architektury nie byłoby zapotrzebowania na energię. Nieprzemyślane działania człowieka w aspekcie ekologii doprowadzają do istotnych, globalnych zmian naszej planety. Ochrona powietrza, wód, przyrody mimo wszystko jest możliwa.
\end{abstract}

\begin{abstract}
Researchers have made a vision of the depletion of coal and oil deposits, which has resulted in the rapid development of research into a new generation of building materials and alternative energy. Unfortunately, every technical solution using recycled materials has as many supporters as hard-core opponents.

Fortunately, it has long been found that the processing of "garbage" is the only salvation for a dynamically developing civilization. Treating the global technological transformation of humanity on a global scale, as a specific type of production, creating waste and pollution, the use of renewable materials on an industrial scale should be considered. Architecture creates and at the same time limits human space, energy is necessary for creative activities, that is, without architecture there would be no need for energy. Unreasonable human activities in the aspect of ecology lead to significant, global changes to our planet. Protection of air, water, nature is possible despite adversity.
\end{abstract}

Słowa kluczowe: recykling, budownictwo pasywne, energia odnawialna, architektura Keywords: recycling, passive housing, renewable energy, architecture

\section{Wstęp}

Do zdefiniowanych naukowo zagrożeń globalnych, możemy zaliczyć tzw. 4P, czyli: pollution, poverty, proliferation, population (skażenie środowiska, nędza, zbrojenia, przeludnienie). $Z$ analiz naukowych wynika, że ludzkość konsumuje poniżej $1 \%$ ziemskiego pierwotnego produktu netto, lecz niszczy aż 40\% jego zawartości.

Człowiek ingeruje w klimat, atmosferę, poziom wód, sposób użytkowania ziemi i nazywa to wszystko nowoczesnymi technologiami energetycznymi. Ale jest jeszcze jedna forma ingerencji człowieka w środowisko. Zanieczyszczenie falami elektromagnetycznymi, które można porównać do skażenia chemicznego lub zagrożenia hałasem.

Według danych Międzynarodowego Biura Rejestracji Częstotliwości Radiowych (IFRB) liczba źródeł pól elektromagnetycznych na świecie zwiększa się każdego roku o 6 proc.

\section{Introduction}

Among scientifically defined global threats, we can mention the so-called "4P", namely: pollution, poverty, proliferation and population. Scientific studies have concluded that Humanity consumes less than $1 \%$ of earth's net primal product, but destroys as much as $40 \%$ of its contents.

Man interferes with the climate, atmosphere, water level, land use and calls all of this modern energy technologies. But there is another form of man's interference in the environment. Pollution with electromagnetic waves, which can be compared to chemical pollution or the danger of noise. According to information provided by the International Frequency Registration Board (IFRB), the number of sources of electromagnetic fields around the world is increasing at a rate of $6 \%$ per year. 
Smog elektromagnetyczny jest wszechobecny, a tworzą go wszystkie używane przez nas urządzenia elektroniczne. Czy więc architektura odnawialna nie jest lekarstwem na taka działalność człowieka, a przynajmniej suplementem diety? Istnieją jednak również czynniki pozaludzkie, czysto przyrodnicze, naturalne, jak zmiana bieguna magnetycznego, zmiany globalne wystepujace mniej więcej co 30 tys. lat, tj. okresy lodowcowe i międzylodowcowe, czy perspektywa chmur pytów wulkanicznych lub gwiezdnych, które zakryia Stońce na tysiące lat. I na to mamy nikły wpływ.

Natura jest niewygodna. Trawa jest twarda, wilgotna, petna obrzydliwych insektów. Gdyby natura byłaby wygodna, ludzkość nie wymyślitaby architektury?

Pomijając intensywny rozwój cywilizacji oraz świadomości wspomnianej ludzkości, teoria ta wydaje się godna zastanowienia. Wszechstronne działania inwestycyjne, zarówno twórców (od pewnego czasu zwanych architektami) jak i budowniczych, zblizały niekiedy człowieka do wymarzonego ideału

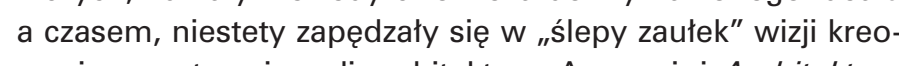
wania przestrzeni, czyli architektury. A przecież Architektura jest mądrą, skoordynowana grą brył w świetle². Nadmierne komplikowanie, zarówno formy jak i funkcji obiektu, nie jest zatem logicznie uzasadnione.

Może właśnie takie przemyślenia skłoniły współczesnych architektów do poszukiwań inspiracji bezpośrednio w naturze. Stąd krąg zainteresowań zamknął się wokół architektury organicznej, pozwalającej w coraz większym stopniu wykorzystac zarówno naturalne formy jak i materiały.

Czyż można być bliżej natury niż mieszkając pod ziemią, a zwłaszcza nie wykorzystując do tego celu ogólnodostępnych materiałów budowlanych. Granada ma obecnie największa populację jaskiniową w Europie, a dzielnica jaskiń w Guadix w Granadzie - najwyższy wskaźnik zamieszkałych jaskiń w Hiszpanii.

Mniej znaczy więcej ${ }^{3}$

Ale niezależnie od wielkości czy ilości istotny jest również rachunek ekonomiczny, a często warunki geopolityczne czy wręcz działania wojenne.

Obecnie przypuszcza się, że w dzielnicy jaskiń w Guadix znajdującej sie za Calle de San Miguel, w tych podziemnych domach może przebywać ponad dziesięć tysięcy mieszkańców. $W$ tych podziemnych obiektach utrzymuje się przez cały rok, w naturalny sposób temperatura około dwudziestu stopni Celsjusza, podczas gdy na zewnatrz w okresie letnim temperatury sięgaja czterdziestu stopni, a podczas zimy często to niezwykłe osiedle okrywa śnieg.

Ten niezwykły labirynt pomieszczeń mieszkalnych nie do końca jest tworem natury, lecz dziełem człowieka przez wydrążenie jaskiń w miękkim piaskowcowym górotworze. Znane sa dowody na istnienie mieszkan w jaskiniach na tym obszarze już w czasach arabskiej inwazji na Iberię $w$ VIII wieku, jednak uważa się, że główny labirynt domów powstał w XVI wieku, kiedy po udanej inwazji chrzescijanskiej na ten region, Maurowie, obawiając się prześladowań w Guadix ze strony ich zdobywców, uciekali masowo z miasta na pobliskie wzgórza.
Electromagnetic smog is ever-resent, and it is mainly created by the electronic devices that we all us Is renewable architecture the cure for this type of human activity, or is it at least a dietary supplement? related, purely environmental and natural, like the changes in the magnetic poles, global changes tha occur more or less every 30 thousand years, e.g. glacial and inter-glacial periods, or the perspective of volcanic or star dust clouds, which block out the sun for thousands of years a

"But nature is so uncomfortable. Grass is hard and lumpy and damp, and full of dreadful black insects. [...] If Nature had been comfortable, mankind would never have invented architecture."

The intense development of civilisation and human awareness aside, this theory appears to be worthy of consideration. Comprehensive build ing efforts, of both the authors (who have been
called architects for some time) and builders o structures, have at times drawn mankind closer to their imaginary ideal and, at times, have unfortunately caused it to go down a "dead end street" in terms of the vision of the creation of space, or in other words - architecture. But "Architecture is the learned game, correct and magnificent, of forms assembled in light" The excessive complication not logically justified.

Or perhaps it is this type of reasoning that has
convinced modern architects to search for inspiration directly in nature. Thus the field of interest has locked itself around organic architecture, allowing us to make use of both natural forms and materals towards a greater degree. Can we be closer to nature than when we live underground, especially materials to this end? Granada currently has the greatest cave-dwelling population in Europe, and the cave district in Guadix in Granada - the highes index of inhabited caves in Span.

"Less is more"s.

But regardless of size or number, it is economic balance that is important, often in addition to geo-

It is currently believed that over ten thousand resdents can inhabit these underground houses in the cave district of Guadix, located behind Calle de San Miguel. A temperature of around 20 degrees Celsius is naturally maintained in these underground structures year-round, while outside summer temperatures can reach up to forty degrees, ment in winter. This extraordinary labyrinth of residential spaces is not purely a work of nature, bu the work of man, achieved through tunnelling in the soft sandstone formation. We have evidence for the existence of living spaces in caves in this area already during the Arab invasion of lberia in the eighth century, however, it is believed that the century, when, after a successful Christian int sion of the region, the Moors of Guadix, fearful of persecution at the hands of the conquerors, fled

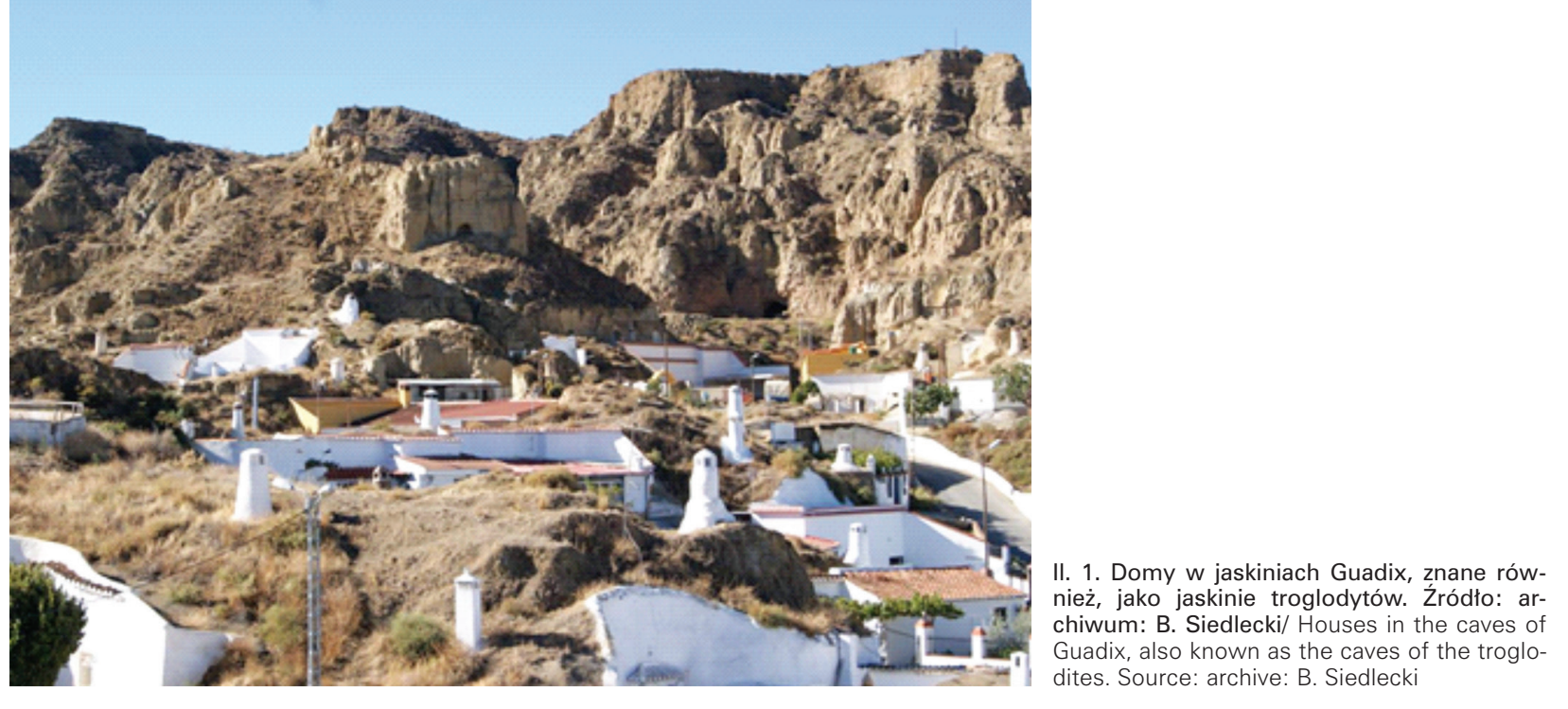

Wspótcześnie pomieszczenia domów w dolnych grotach są starannie wykonczonymi jaskiniami, z biezącą woda Wiele z tych rezydenci zosego w najwyższym standardzie. Wiele $z$ tych rezydencji zostało w zwiększajacc tym samym dostęp śswatla sionecznego. Natomiast w niektorych strefach dzielnicy, jedynymi dowodami na istnienie podziemnego życia są widoczne w skale pobielon drzwi, niewielkie okna i kominy rozmieszczone wzdłuż zboczy masywu górskiego. W tym niecodziennym krajobrazie można również napotkać ślady minionych czasów $\mathrm{w}$ formie starożytnych, opuszczonych, czesto zarosniętych jaskiniowych wejśc.

\section{Teza}

Porównując system zabudowy dzielnicy Guadix z innym naturalnym sposobem egzystencii, jaki stanowia kopce termitów możemy wysunć teze, że dla uzyskania wieloptaszczyznowe oo komfortu klimatycznego nie sa niezbedne istotne, szeroko ogólnych zasadach recyklingu, czyli maksymalizacji ponownego wykorzystania materiałów odpadowych lub rozbiórkowych, z uwzględnieniem jak najmniejszych nakładów na ich wtórne dostosowanie. Działania takie mają na celu ochrone surowców naturalnych, służących do ich wytworzenia oraz surowców służących do ich późniejszego przetworzenia. Ni wolno jednak pominać zagadnień, jakie nowe zagrożenia dla przyszłości architektury mogą generować takie technologie. Zagadnienia odnawialności należy rozpatrywać, co najmnie w dwóch obszarach: takiej technologii związanej z produkw dwóch obszarach: takiej technologii związanej z produkcją dóbr, która zmniejszy nakłady wtórnego wykorzystania materiału oraz sposobu organizacji przetworzenia powstajacych z tych materiałów odpadów. Założenia recyklingu zakładają wymuszanie odpowiednich postaw producentów dóbr, sprzyjających produkcji materiałów jak najbardziej odzyskiwanych oraz tworzenie odpowiednich zachowan u odbioców tych dóbr. the city en masse to the surrounding hills. The modern rooms of homes in the lower caves are electricity and the highest standard household appliances. Many of these residences have been expanded outwards to include additional rooms and terraces, thus increasing access to sunlight. However, in some zones of the district, the only evidence of the existence of subterranean life are the whitened doors visible in the rock, in addition to small windows and chimneys along the walls we mountain massif. In this unusual landscape of ancient, abandoned and often overgrown cave entrances.

2. Thesis

By comparing the system of the buildings of Guadix with a different natural form of existence constituted by termite mounds, we can make the climentertion penditure is both necessary and significant newable architecture - based on renewable materecycling, which is the maximisation of the reuse of waste materials or that obtained during demoof their secondary adaptation. Such efforts are aimed at protecting the natural resources used to mantacture them, as well as the raw materials we should not ignore such issues like new threats to the future of humanity that such technologies can generate.

The issues of renewability should be considered in at least two areas: the type of technology of the production of goods that can lessen the cost of the reuse of materials and the manner of the organfrom the processing of the waste produced assume forcing certain stances on goods mcling facturers, leaning towards production using mate rials, should be based on the general principles of lition, taking into account the lowest possible cost 
Rozszerzając rozważania dotyczące zagadnień architektury izować zjawiska, jakie zachodza w jej naturalnej formie. W skali globalnej większe koszty ponosimy na chłodzenie niż na ogrzewanie wszelkich obiektów. Niestety w niewielkiej skali wykorzystujemy zjawiska naturalne, które mogą w znacznym stopniu wpłynąc na obniżenie kosztów eksploatacii. Najwieksze straty generuje system wentylacii. Analiza systemu wentylacii indukowanej jaka stosuia termity pozwolitaby na zastosowanie podobnych rozwiazań w budynkach mieszkalnych. Czy wobec tego należy uwzglednić globalistyczny chychter potrzeb mieszaleź

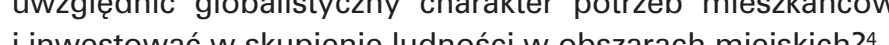

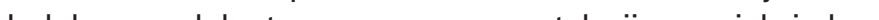
Indukowny lub ca termitow "Oww wiatu na szczycie stosu (na wysakosci ok. 2 m), w porównaniu z mnejszymi pred Zjawisko to prowadzi do uzyskania rozinicy cishieh w pionie przez centralny komin kopca generując strumien powietrza stanowiący naturalną wentylację. To proste zjawisko nieco się komplkuje w przy wadu kopców bez dużego otworu na górze, podobnie jak w naszych obiektach mieszkalnych. I na to termity mają receptę, tj. wentylacja termosyfonowa napędzana metabolizmem. Macrotermes to rodzaj termitów należących do rodziny Termitidae i szeroko rozpowszechnionych w Afryce i Azji Południowo-Wschodniej. Podobnie jak inne rodzaje Macrotermitinae, konsumują martwy materiał roślinny prowadząc hodowlę grzyba Basidiomycete z rodzaju Termitomyces na galeriach wewnątrz - często bardzo duzych - kopców termitów. Pomysł realizowany przez owady jest skutecznie oparty na "zyskach ciepła z mieszkańców". Wszystkie te małe, ruchliwe owady, poruszające się wokół rosnącego grzyba kumulują ciepło. Pojedynczy osobnik nie generuje go zbyt dużo, ale przy milionach w każdym gnieździe przyrost ciepła zaczyna być istotny.

Gorace powietrze unosi sie na skutek konwekcii, w wyniku czego, może wznieść sie przez główna strukture komina a następnie przez czapkę, która ma liczne rozgałęzione tunele rials that are as recyclable as possible, as well as facilitating appropriate behaviours among the consumers of said goods.

Expanding the discussion of the problem of rephenomena that occur in its natural form. On the global scale, the costs of cooling are much greater than of the heating of all manners of buildings. Unfortunately, we use natural phenomena that can greatly influence the lowering of operational costs on a very small scale. The greatest losses are generated by the ventilation system. An analysis of would allow the use of similar used by termites tial buildings. Should we, in light of this, take into account the globalist character of the needs of residents and invest in concentrating the population in urban areas? ${ }^{4}$

The induced or stack ventilation process in the de sign of a termite mound featuring an "open stack" yields higher wind speeds at the top of the stack er wind speeds at ground level. This phenomeno leads to obtaining a vertical pressure difference in the central shaft of the mound, generating an air stream constituting natural ventilation. This simple phenomenon becomes slightly complicated in the case of mounds without a large opening a the top, similarly as in our residential buildings. in the form of thermosition to that problem as well, metabolism. Macrotermes is a genus of termites that belong to the Termitidae family that is very common in Africa and South-East Asia. Similarly to other genera of Macrotermitinae, they consume dead plant material through cultivating the Basidiomycete fungus of the genus Termitomyces mounds. The ide implemented by the - termite effectively based on "thermal ains from occu pants". All of the small, busy insects accumulate heat when moving around the growing fungus. A single specimen does not generate that much

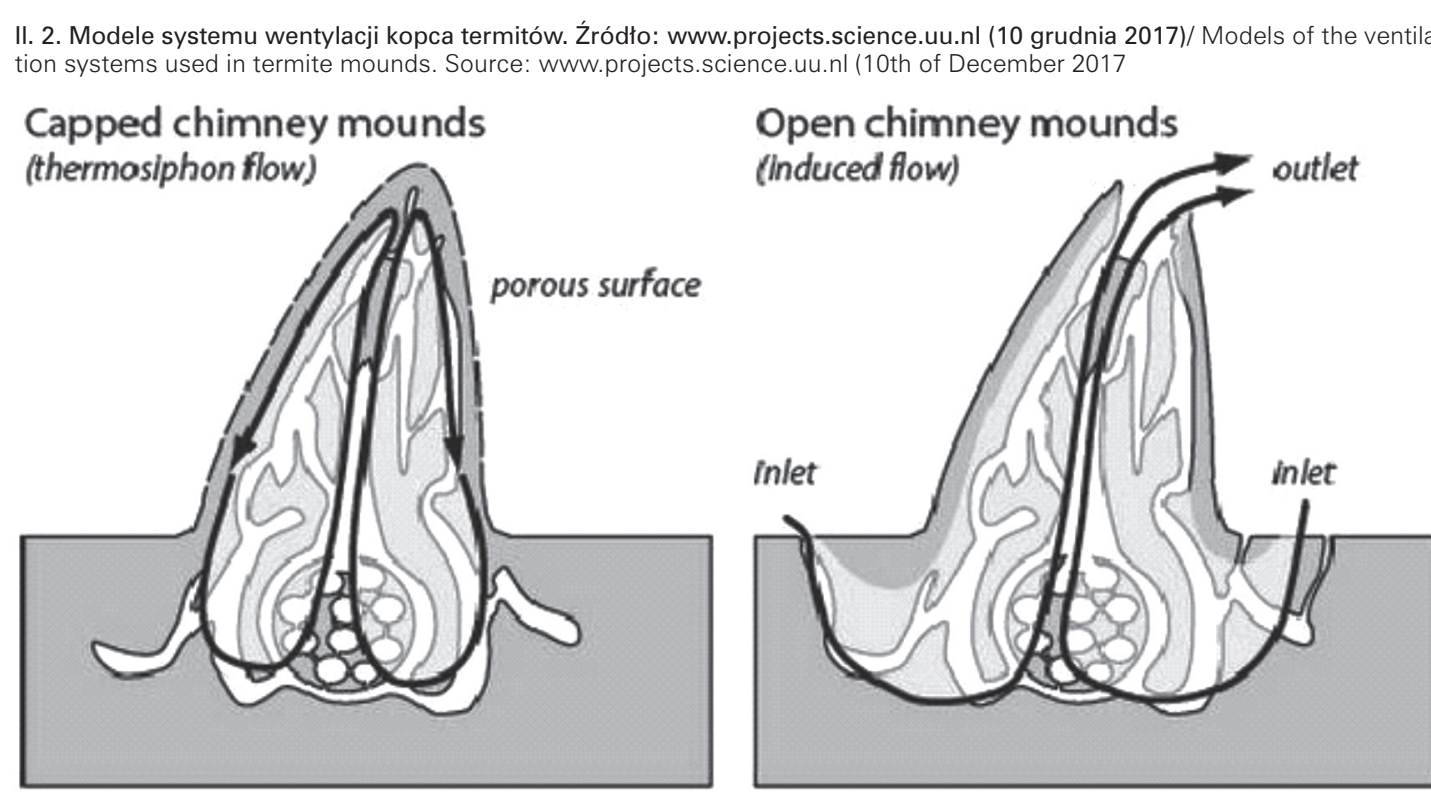

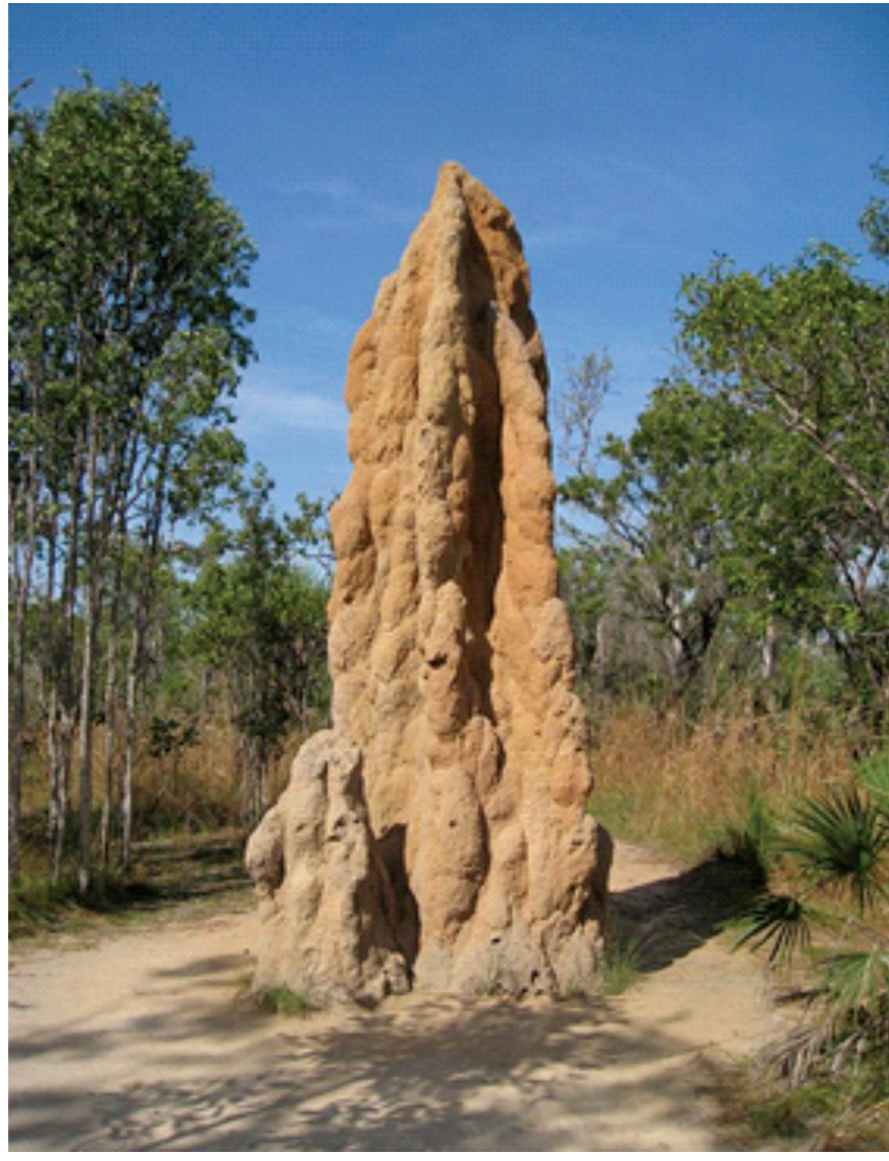

między kominem a powierzchnią. Gdy powietrze unosi się, tworzy podciśnienie u podstawy gniazda, która jest wypełniana przez powietrze wchodzące do gniazda z kanałów zewnętrznych na poziomie terenu.

Najwięcej dostojeństwa mają najprostsze formy ${ }^{5}$.

Analizujacc naturalna forme kopca termitów nasuwa się skojarzenie z twórczością Antonio Gaudiego. Inspirując się naturalnymi formami występującymi w przyrodzie, prowadzi własne eksperymenty związane z rozkładem obciążeń, czyl przenoszeniem ciężarów na różne elementy budowli. Jego specjalnie przygotowany pokój, w którym zawieszone były skomplikowane sieci ciężarków i sznurków, pozwolił Gaudiemu eksperymentować z nietypowymi rozwiązaniami technicznymi. Obecne długotrwałe obliczenia na zaawansowa nych programach komputerowych wraz z wykonywaniem symulacji wirtualnych 3D potwierdzają poprawność przyjętych schematów statycznych.

\section{Analiza}

Podobne, organiczne formy posiadają obiekty mieszkalne określane, jako „Earthshipy”. Są to pasywnie ogrzewane, autonomiczne budynki konstruowane niskim kosztem z lokalnie dostępnych materiałów, w tym z ziemi i odpadów. Czy warto, więc rozważać takie budownictwo, w jakim stopniu jest on opłacalne i jaki jest aspekt zdrowotny takich rozwiązań? Miej-

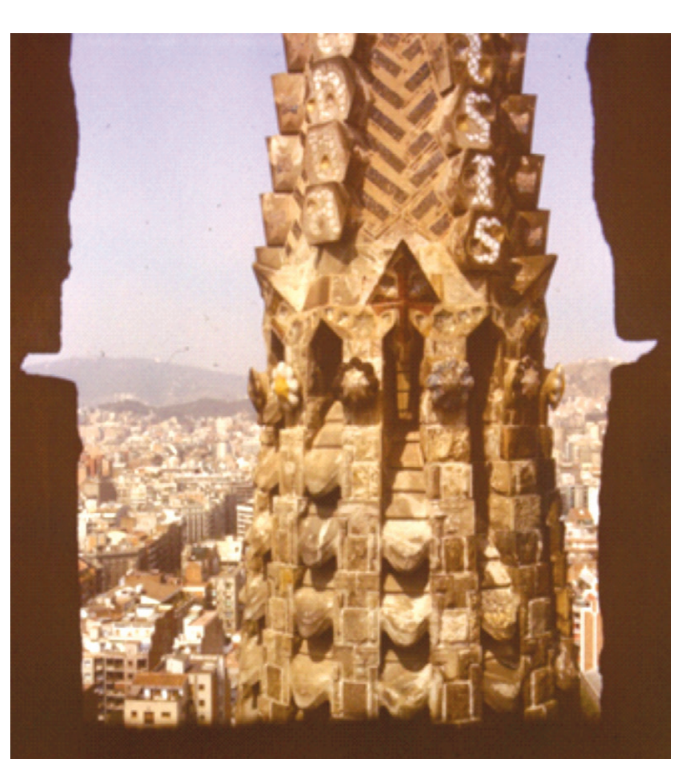

II. 3. Kopiec termitów. Żródło: www.abc.net.au (dostẹp: 20 listopad 2017)/A termite mound. Source: whw

II. 4. Wieża katedry Sagrada Familia. Ż́ródto: archiwum:
B. Siedlecki)/The tower of the Sagrada Familia basilica. B. Siedleckil/ The tower of the Sagrada Familia basilica.
Source: archive: B. Siedlecki

heat, but considering there are millions of them in every nest, the heat gain starts to be quite substantial.

Warm the air rises due to convection, and as a result can rise through the main structure of the stack, and then through the cap, which features the surface. When the air rises, it creates negative pressure at the base of the nest, which is being filled by air coming inside it through external ducts at ground level.

"The simplest forms have the most grandeur." When analysing the natural form of the termite of Antonio Gaudi. Inspired by natural forms occurring in the environment, he performed his own experiments associated with load distribution, which is the transfer of loads to different elements of a structure. His custom prepared room in which he had hanged complicated networks of with atypical technical solutions. Current tedious calculations performed using advanced computer software, along with performing virtual 3D simulations, have confirmed the appropriateness of the statical schemes that he adopted.

\section{Analysis}

Residential buildings called "Earthships" have autonomic buildings built at a low cost from loca- 
scowe Plany Zagospodarowania Przestrzennego rozróżniają w sposób istotny zabudowę miejską od tej w strefach małych miast i wsi. O ile sytuacja w centrach miast poprawiła sie wraz ze zmianami gospodarczymi, o tyle zagospodarowanie przestrzeni w podmiejskich dzielnicach mieszkaniowych jest nadal złe

Architektura polega na zachowaniu trzech zasad: trwałości, użyteczności i piękna?.

Czyż takich właśnie cech nie posiada natura w czystej formie? Stoma i glina to najstarsze materiały budowlane, stosunkowo najzdrowsze i najbardziej ekologiczne z obecnie dostępnych na rynku materiałów budowlanych. Trudno uwierzyć, ale powszechnie używane w Polsce do budowy domów i ociepleń budynków jeszcze po Il wojnie światowej. Dopiero rozwój cementowni i hut wyksztatcił pęd ku betonowym i żużlopodobnym domkom, które dalekie są od ekologii generując swoim nym domkom, które dalekie są od ekologii generując

składem trujące emisje i wykrywalną radioaktywność.
Istnieje wiele technologii wynoszenia obiektów, w których Istnieje wiele technologii wynoszenia obiektow, w których
podstawa jest glina. W jednej z nich, formuje się ściany ze podstawą jest glina. W jednej z nich, formuje się ściany ze
szkieletem drewnianym wewnątrz, glinę do wypetniania ścian miesza się z suchą trzciną, z clętą slomą czy wrzosem. Zastosowana glina powinna mieć dużą zawartość piasku, z dodatkiem żwiru, a ściany są ubijane $w$ szalunku pneumatycznie lub wibracyjnie.

Można również ksztattować przegrodę przez formowanie gliny w bloczki, którymi, po odpowiednim stopniu utraty wody, bez wypalania, wypełnia się ściany ze szkieletem drewnianym. Inna metoda to bloczki z ziemi, gliny piaszczystej, suchej, zgniatane w prasach mechanicznych.

O trwałości tych wspomnianych technologii świadczą budowle, funkcjonujące $w$ dobrym stanie od wielu lat praktycznie na całym świecie. Na naszych terenach to m.in. Pałac w Tarchominie pod Warszawa, wzniesiony w XVII w, budynek w Szańcu (woj. krakowskie) wzniesiony w 1932 r, szkoła Podstawowa w Kasince Matej (woj. nowosadeckie) oddana do użytku w 1948 r.

Przeliczeniowy nakład energii na zbudowanie $100 \mathrm{~m}^{2}$ domu jednorodzinnego wynosi odpowiednio:

jednorodzinnego wynosi odpowiednio:
w technologii wielkopłytowej - $180000 \mathrm{kWh}$

w technologii tradycyjnej (cegła) - $80000 \mathrm{kWh}$;

w technologii tradycyjnej (cegla) - $80000 \mathrm{kWh}$;

w technologii ekologicznej (glina + drewno) - $25000 \mathrm{kWh}$ inwestycja jest do $80 \%$ tańsza od metod obecnie stosowanych. Mury z gliny dobrze izolują cieplnie, mają jednocześnie duże zdolności akumulacyjne, co budynkach pasywnych jest istotne.

Współcześnie w Europie z gliny wykonanych jest wiele obiektów, w tym ponad 300 tys. mieszkań w Niemczech. W ilości historycznej zabudowy glinianej przoduje jednak Francja, posiadając ponad 15\% budynków sprzed 1900 r. W rejonie Grenoble - Lyon - Chacon większość niskich obiektów miejskiej zabudowy jest wykonana z niepalonej gliny, szacuje się, że jest to ok $70 \%$ budynków. [2]

Szczytowym osiągnięciem technologii i konstrukcji obiektów glinianych jest miasto Shibam w Jemenie. Cały kompleks jest całkowicie zbudowany z suszonej gliny. Zrealizowane na
Iy available materials, including earth and waste. Is it worth then to consider such buildings, and health aegree is it economical and what is the health aspect of such solutions? Local Spatial Deings from those in the zones of towns and rural areas. As far as the situation in city centres has improved along with economic changes, spatia development in suburban residential areas is stil poor ${ }^{6}$. "Architecture is based on adhering to three prin-
ciples: solidity, usefulness and beauty" 7

Does nature in its purest form not have these properties?

Straw and clay are the oldest building materials,
and are relatively the healthiest and the most environmentally friendly of the currently available construction materials. It is hard to believe that, but they were commonly used in Poland for the construction and insulation of houses even after ment of cement plants and steel mills that established the drive towards concrete and cinder-like houses, which are far removed from being friendly to the environment, generating poisonous emissions and detectable radioactivity through their composition.

There are many technologies of constructing buildings that use clay as their base. In one while the clay that is used as infill is mixed with dry reeds, cut straw or heathers. The clay used in this system should have a high sand content, with an addition of gravel, and the walls are rammed in a formwork either pneumatically or with the use of

We can also shape a partition through forming content ald without firing, losing some water a timber frame wall. Another method uses blocks made of earth, sandy dry clay, which are compressed in mechanical presses. The durability of the aforementioned technologies is attested by the structures which have functioned in good condition all around the world for many years. our area they include the Palace in Tarchomin the building in Szaniec (Krakowskie voivodship) erected in 1932, as well as the primary school in Kasinka Mała (Nowosądeckie voivodship), which was opened in 1948.

The conversion energy cost of building a $100 \mathrm{~m}^{2}$ of a single family house is, respectively:

$180000 \mathrm{kWh}$ using panel building technology

(b) using traditional technology (brick) nology (clay - timber)

As we can see, the benefits associated with building out of clay are obvious: a project is up to $80 \%$ cheaper than when adopting currently used methods. Clay walls provide good thermal insulation, In addition to having considerable accumulative Currently there are numerous buildings built oot of clay in Europe, including over 300 thousand dwellings in Germany. In terms of the historic

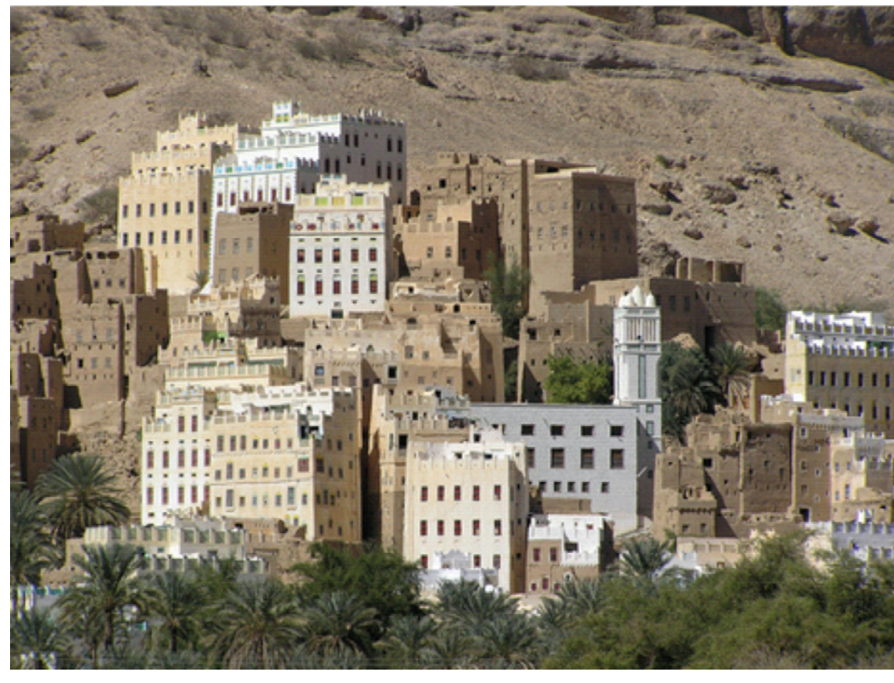

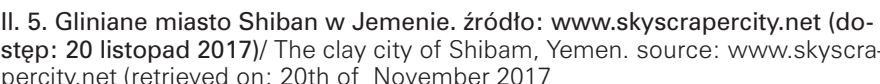

przełomie XIX i XX w. budynki mają wysokość do 10 pięter. Warto podkreślić, że glina posiada niewielki opór dyfuzyjny utrzymuje własciwą wilgotnosc w mieszkaniu. Istotne cechy to: ttumienie halasu, oczyszczanie powietrza ze szkodliwyc substancji i antystatyczność. Zawartość związków wapnia blokuje rozwoj mikroorganizmów. Optymalna wilgotność powietrza w pomieszczeniach mieszkalnych powinna wynosic od 40 do $70 \%$. Glina dzięki swoim właściwościom wchłaniania i oddawania wody, pozwala na utrzymanie wilgotności na poziomie około $50 \%$

Słoma, jako dopełniający wspomnianą technologię materia budowlany, jest materiałem naturalnym, który w odpowiednich warunkach może zachować swoją trwałość. Jedna w niesprzyjajaccych warunkach klimatycznych, słoma podleg procesowi rozkładu tak samo, jak wszystkie naturalne matein drewno czy bawełna. Zakres korozji zależy przede wszystkim od wilgotności i temperatury.

Sprasowana słoma charakteryzuje sie dobrym współczynnikiem przzwodzenia ciepta - zbliżnym do wartości styropion czy wetny mineraj, czyli $0,04 \mathrm{~W} / \mathrm{m}^{2} \mathrm{~K}$. Stosuiac do budowy bloki o gestości co najmniej $120 \mathrm{~kg} / \mathrm{m}^{3}$, zapewniamy trwałośc realizowanej przegrody. Wytwarzane zwykle ze słomy żytniej pszennej, pszenżyta, owsa i mieszanek zbóż, są gotowe do użycia bez dodatkowych procesów technologicznych.

Należy zwrócić uwagę na fakt, że słoma zawiera dostatecznie dużo energii, aby umożliwić rozwój mikroorganizmów. Pokrywając gliną powierzchnie zewnętrzne i wewnętrzne, ograniczamy dostęp tlenu. Mikroorganizmy w zamkniętej warstwie słomy zużywają tlen, zamieniając go na dwutlenek węgla, co skutecznie ogranicza ich dalszy rozwó

4. Podsumowanie

Współczesne technologie budowlane bazują głównie na monolitycznych konstrukcjach żelbetowych, stanowiących uziemion klatkę z siatki stalowej, jaką stanowi zbrojenie obiektu. Działanie klatki Faradaya znamy z lekcji fizyki szkoły średniej, na- amount of clay buildings, however, France is clearly in the lead, with its share of over $15 \%$ of buildings from before the year 1900. In the Grenoble are made from nonfired clay, and it is eutings they comprise around $70 \%$ of all buildings. The peak achievement of clay building technology and structural engineering is the city of Shibam in Yemen. The entire complex is entirely built out of dried clay. The buildings, built at the turn of the nineteenth and twentieth century, have a height up to 10 storeys.

Would be worth to highlight the fact that clay has ate humidity in an apartment. Significant characteristics include: noise dampening, purifying the air from harmful substances and antistatic properties. The inclusion of calcium compounds blocks the development of microorganisms. An optima air humidity in residential spaces should be between 40 to $70 \%$. Clay, thanks to its properties of to reting anumidity level of around $50 \%$.

Straw, as a supplementary construction material for this technology, is a natural material, which, in appropriate conditions, can maintain its durabilstraw is subjected to the same decompositio process as all natural materials like paper, timber or cotton are. The process of corrosion depends Cor

Compressed straw is characterised by a good heat transfer coefficient - close to the value of Styrofoam or mineral wool, which is $0,04 \mathrm{~W} / \mathrm{m}^{2} \mathrm{~K}$. Using int build blocks with a density of at least $120 \mathrm{~kg}$ me ensure the durability of a partition. Manumixed grain straw, they are reat, triticale, oat and mixed grain straw, they are ready to use withou

contains sufficiently enough energy to enable the growth of microorganisms. Covering the exterio and interior surfaces with clay limits access to oxygen. Microorganisms consume oxygen in the enclosed straw layer, turning it into carbon dioxid wich

\section{Conclusion}

Modern construction technologies are mainly based on monolithic concrete structures, consti-
tuting an earthed cage of steel netting that is the reinforcement of the structure.

We know the operational principles of the Faraday cage from high school physics lessons, while the influence of the Earth's electromagnetic radiatio tion for the appropriate facilitation of the process of cell metabolism. Healthy tissues can exist and be generated only under the influence of the appropriate activity of electromagnetic fields. The way of life of the civilised man leads to a deficit of movement, which is an energy deficit. The pulsating magnetic field is capable of eliminating .

subjected to firing, they have different properties Straw has been replaced by Styrofoam and min- 
